$S F 510$

$Q_{2} P_{4}$

1908 

Recommendations as to the Trapping and Care of Quail.

Use of Poison for the Extermination of Vermin and Crows.

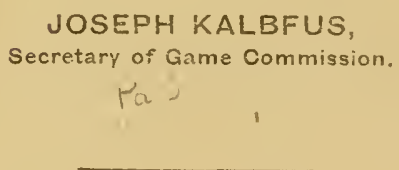

HARRIGBURE, PA.:

HARRISBURG PUBLISHING CO., STATE PRINTER. 1908. 

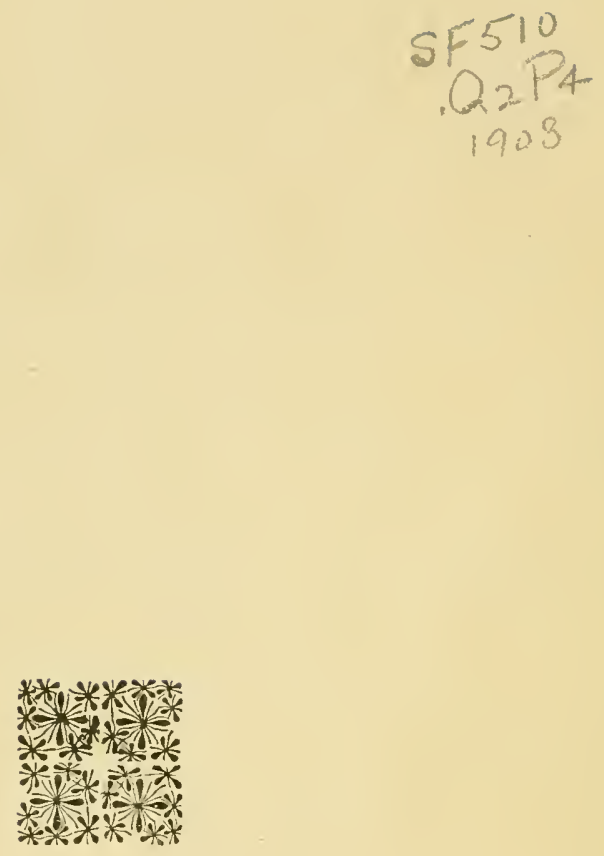

D. 0 or Di
M. $18^{\prime} 908$ 


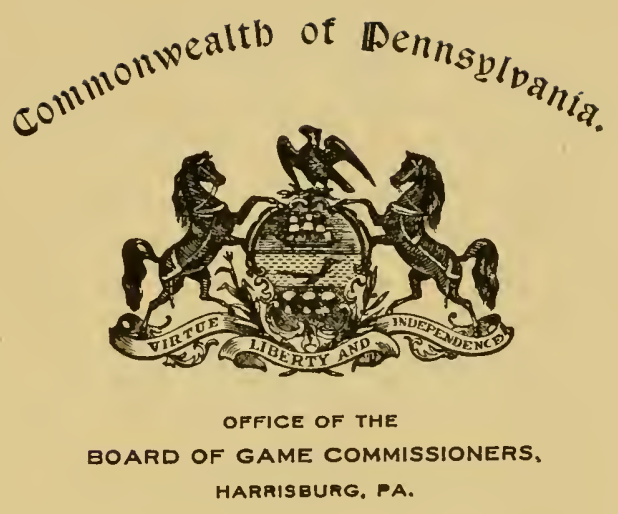

January 1st, 190 t.

Dear Sir: By act of Assembly, it is made the duty of the Board of Game Commissioners to protect the game and wild birds of the State, I take it this duty extends beyond matters specifically mentioned in the statute. That the purpose of the law is to save the game and wild birds from extinction, and that it is as much my bounden duty to protect the game and wild birds from destruction through the agency of four footed animals, predatory birds, or the elements, as it is to say these same things shall not be taken by man, except under the letter of the law. I cannot believe that the Game law is intended for a purpose other than benefit to all the people of the State, or that it is my duty to arrest a poor man who may kill game out of season, when he needs the same for food, and then stand with folded arms and see game of like kind destroyed by storms, vermin, or wild animals, big or little.

With the idea, then, that it is my duty to give all the protection in my power to the game and wild birds of the State, I desire to make some suggestions.

I will not attempt in this letter, except in a limited way, to touch upon the value of the life work of the birds. I do want it understood, that as the illustration I may use shows the value of the bird named, so each family of our birds has its specialty, each doing a particular work that no other family attempts to do, except to a limited extent.

Professor Surface, Economic Zoologist of this State, tells me the annual loss to Agriculture, in the United States, aggregates scores of millions of dollars from the ravages of plant lice alone. That 
if the natural increase of plant lice was not curbed in some way, this world would not be inhabitable by man, at the end of ten years.

One of the great protectors of plant lice is our common ant, which carries the egg of the plant louse below the frost line in winter, carries the young louse out and places it on the plant in the spring, getting therefrom, in return, what is known as honey dew, each ant protecting and caring for vast numbers of lice, just as the farmer cares for and protects his cattle for the return they give.

One of the great destroyers of ants is our common flicker or yellow hammer. This bird is the most terrestrial of all wood peckers, and takes fully seventy-five per cent. of his food on the glound. The examination of many of the stomachs of these birds has proven conclusively that more than one-half of the food of this bird, the year round, is made up of ants, and demonstrated the capacity of a gingle flicker to consume nine thousand ants at ome meal.

No game bird seens to have a firmer hold upon the public mind than the common quail, or "Bob White," and a study of this bird, andertaken by the Biological Surrey at Washington, demonstrates, by almost limitless examination and experiment, that the economic value of the quail is equalled by but few birds, and exceeded by none. His food supply is more raried than that of most birds, and is almost without exception drawn from a source through which nothing but good can result. He cousumes many things, such as potato bugs, chinch bugs, the cotton boll weavel, certain caterpillars, spiders and other inserts, that most birds avoid, and that, when taken at all by such other birds, are eaten to a limited extent only. Professor Surface says, in his Bulletin of January, 1904: "No birds on the farm are more valuable as seed eaters and insect destroyers than the common quail."

In addition to the value of the life work of all game birds is the value that cannot be expressed in words or figures, of a day afield with gun and dog, and $I$ know there is no sportsman who will not appreciate what I mean, when this is said. There is a benefit derived, that no one who fails to indulge in this sport can realize, a benefit that is not drawn through the killing of the birds only, and that comes to no two men exactly alike. 'The working of a dog speaks in different language to difierent men. From the moment the trail i⿶ struck until a dead bird, beld only by the tip of a wing, is brought and laid at one's feet, all else, business cares and engagements, sorrows and joys outside, are alike forgotten, in the work of that dog.

Six times to my certain knowledge, since I first began to talie a special interest in this work, quail, because of severe winter's and the slaughter by market hunters, had become almost extinct in Peangylvania. Six times the sportsmen of this State, as an organi- 
zation, with a limited number of outsiders, went down into their pockets and furnished the cash wherewith to buy quail in other States and bring them into this State.

During February, Marcl and April of the year 1906, the Game Commission purchased and brought into this state from Mlabama, about 3,700 quail, paying for same at the rate of nine (9) dollars per dozen, 6 males and 6 females. These birds were placed by Deputy Game Protecto's in almost every county in the State. The ouly connties overlooked or passed, being those wherein the people took so little interest in the work of game or bird protection as to either refuse or neglect to recommend the appointment of a protertor within their borders. Many quail have also diwing the past spring been brought into the state by private individual:

rine same thing has been done every year to a more oí lesg degree for many years, and I feel perfectly safe in saying that were it not for: this importation of quail there would not be one single cover in this state to-lay. rhe killing of these birds for the market has to a rery great extent ben stopped. So likewise have been closed the avenues through which live birds can be secured from the outsice. Fire rears ago quail for propagating purposes could be secured without linit from almost erery State of the South and west. To-day I can comt the States upon the fingers of one baxd from which these birds ran be secured for any purpose, the supply being limited from these states and the price three and even fire times what it was five rears ago. Mauy of the States that only three years or four years ago were exporting qual in apparently unlimited numbers, are to-day trying their best to secure a fer thousand or eren hundreds alive for propacating purposes. It is reporter that more than 400,000 quail were shipped from Alabama alone during the rear 190. Sone 30,000 of this number were shipped alive for restocking pminoses. The balance being dead were invoices to cold storage houses in the North. In 1906 the Legiglature of Alabama forbade the shipment of quail either living or dead. ont of her: boundaries. Thus another State has closed its doors agninst us in this respect. It seems to me that we are forced therefore into the position where we must protect and save our own birds, if we loye to have any in years to come. Aside from statutory exartment every citizen and lover of the qual has his work to do. I, therefor, beg each individnal, I beg the farmers who derive more benefit from the life work of all kiads of birts than any other class, I beg the sportsman with his limited benefits of a day afield, every boy and girl who takes pleasure in our birds, every professed Christian of this state to "not pass by upon the other side." The winter, figuratively speaking, in its most termible form is indeed at hand for 
our birds. Don't let them die. I assure you in protecting them you are benefiting yourselves.

\section{CAP'TURE OF QUAIL.}

The law at this time permits the capture of quail from the first of January to the first of April following for the purpose of keeping them alive during the winter and the additional purpose of separating a covey, but for no other purpose whater'r. (See section 18 of the act of April 22, 1905.) And any method through which this can be accomplished without injury to the birds may be used. They may be led into a trap or nct (see ('ut), by lines of buckwheat or sereenings or other food, and after buing captured they may be easily kept in cages or coops of proper dimensions (sce cut attached).

Find where the birds are in the habit of feeding or runing, set your net or trap in such place.

Notice the strips innuing lengthwise of net. Their purpose is to widen that part of the net resting on the ground. Without them erery particle of food can be taken by the birds without going into the net.

Notice the light board with cross strips laid in the funnel of the net as shown in front riew. This board while not absolutely necessary, is a great help in luading the birds into said net. The cross strips hold the food and help the birds to find the opening in the funnel.

Sparrows can well be taken through the use of the same method if the mesh is small enough.

Always keep a sharp watch over your net when it is set, making it a point to look it orer frequently each day, otherwise you may cause the destruction of the covey rou hope to preserve, for when quail are thus canght in a net they fall easy rictims to the attacks of cats, weasels, hawks or other predatory creatures.

Remember it is a violation of the law to trap or net quail for any purpose, excepting that of leeping them alive during the winter or for the purpose of separating a cover. Ser. 18, act April 22, 1905. All quail thus taken must be released as soon as the weather is suitable in the spring. The penalty for catching quail in this manner' for any other purpose than that above stated as fixed by section 9 of the act of June 4, 1897, is fifty dollar's for each offense. This is simply for the taking of the birds in any manner excepting witl a gun. There is also a penalty of twenty-five dollars for each bird taken out of season. 


\section{CARE OF QUAIL.}

A good plan is to secure a good size room, say fourteen feet by fourteen feet, being sure all openings whereby rats or weasels can enter are closed. Cover the windows with woven wire and leave it open so that plenty of fresh air will be given. The quail is a very hardy bird and is not liable to freeze, so long as it has plenty of food and is kept dry. Place a pile of brush, perfectly evergreen, into one cormer, into which the birds can retreat when alarmed. I have known of the keeping of many quail in this way.

One of the great objections to this method is that when suddenly frightened the birds are liable to fly against the window screens and walls, in many instances injuring themselves seriously. I would therefore recommend that the birds be confined in boxes or coops especially provided for that purpose, said box to be placed in a room previously made vermin proof and well ventilated.

A good box or coop (see cut) can be cheaply and easily made by taking two boards, say four feet in length and nine inches in height (1) not too high or too low. Nail crosswars to these two boards othęr boards, say two and one-half or three feet in length (2), so that the short board will form the bottom and the long boards the sides of the proposed coop or box. Board up one end (3) placing wire netting, one inch mesh, on the other end. (4). First inserting a strip at the top of that end. (J). This strip serves the double purpose of a support to the sides and a foundation upon which to tack rour wire. Eighteen or twenty inclies from said wire end, fasten crossways in said form a board the same width of side boards, (6), thus making two compartments. From the middle of this board to the middle of the rear end and running parallel with the sides fasten a second partition (7), thus maling three compartments to the box. Before nailing the first described partition cut two openings (8) about four inches by four inches, placing them so that they will come about the middle of the front end of each of the real compartments, the purpose being to permit the quail, when frightened or disturbed to retreat through these openings into rear opening that will, when finished, be comparatively dark. Attach the blocks thus sawed out, with hinges, leather or otherwise, to serve as doors, so that the birds can be confined in either or both of the rear compartments as desired.

Your are ready now to affix the roof or cover of the coop which in all instances should be made of some rough, course cloth, such as can be obtained by ripping the sewed side and end of a coffee sack. Cut this cloth, so that it will extend over both ends and sides of the box, at least three inches in all directions. Tack a light 
strip, (9) say one inch square, to the edge of this cloth, that will fall orer the sides of the box. Adjust cover so that it extends equally over all parts, then tack securely to the middle division, the one running lengthways. No. 7 . You then have a cover that can be turned back from either side to the middle. The birds can be driven to either side compartment and the door fastened with a button. By turning back the opposite side, the box can be easily and readily cleaned. The birds are to be fed and watered in compartment having wire front.

My method of watering is to afix tin boxes or troughs to either side of this compartment. These troughs are attached so that they are half inside (10) and half outside of said compartment and about three inches from the floor. The boxes are so affixed that they can be taken out at pleasure for cleaning purposes. I find that if these watering troughs are placed too near the floor the quail, which are great scratchers, will keep them constantly filled with dirt.

In affixing water troughs I make a tin box, (11) say three inches by ten inches, soldering on each end about one-third length across said ends a small piece of tin, (12) say two inches in length. This prevents the trough from slipping too far into the box, and serres as a fastening through the use of a button or tack or other appliance that may be considered best. To adjust a through of this kind I make measurement of same on the box, exactly where I desire to introduce it. I bore an inch hole at each end of this measurement and saw out strip from hole to bole as near an inch in width as possible. (13.) From each of these holes, exactly where the end of the trough will come and so same can be inserted therein, I make a saw cut at right angles with and above said first named cut, (14) these cuts being about twice as long as trough is high, all together making a figure something like the cut attached, No. 13 and 14, second riew. If the cuts are'made to correspond with sides of trough there will be no trouble whaterer in introducing or remoring same at pleasure. If adjusted in this way the troughs can readily be cleaned.

For the purpose of giving more light and air than would be admitted through the corer alone I suggest boring one inch holes about three inches apart along the outer sides of rear compartments (15) and partitions, placing these holes about three inches from the floor, or abont breast high to the bird. If placed too high, or where the birds can readily see objects on the outside, they are more easily frightened, than when holes are placed as before indicated.

The sticks or slats attached to the edge of the cloth top can be easily tied with strings to staples driren into the sides of the box, say one string and staple to each end of said strip and one in the 


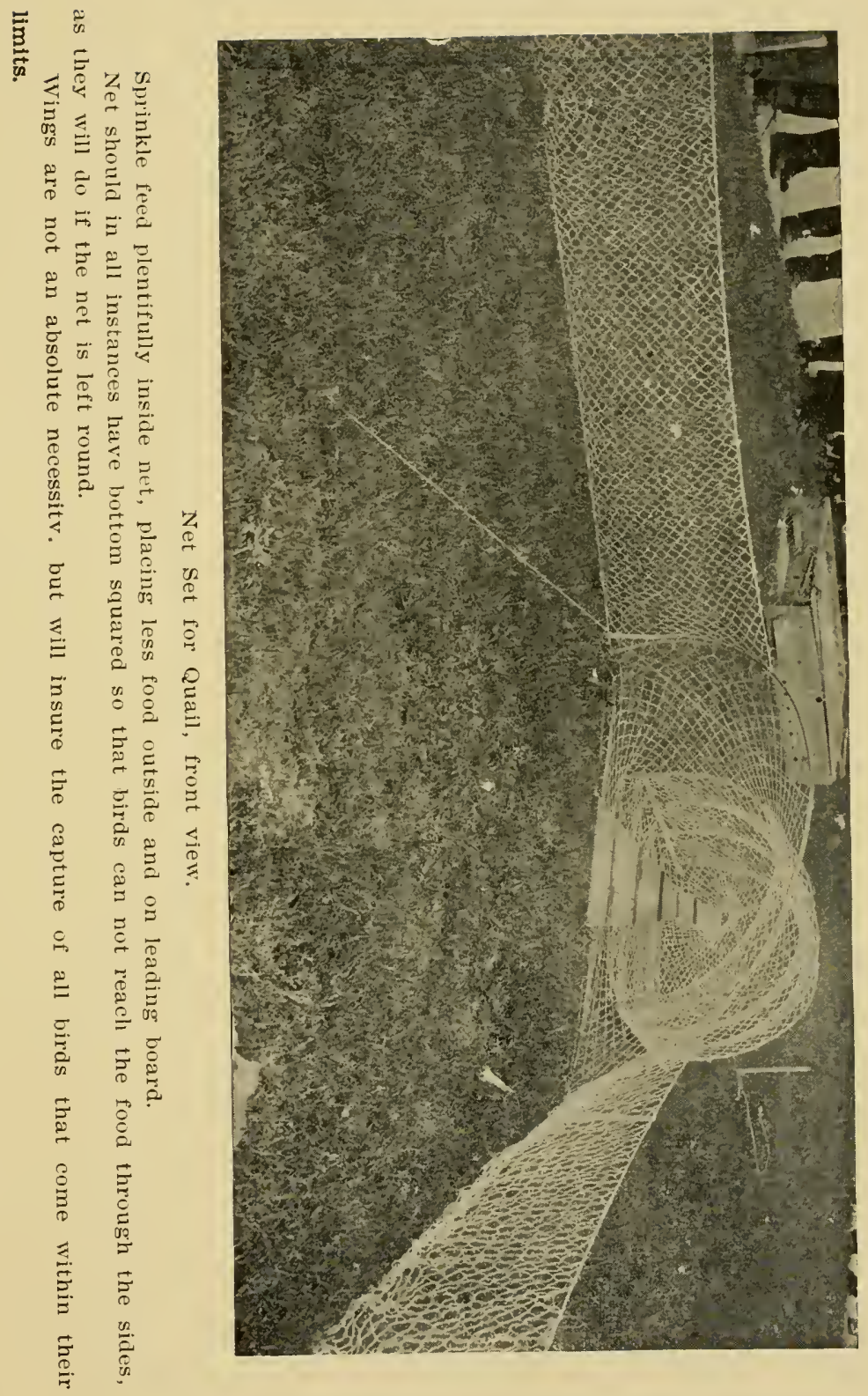






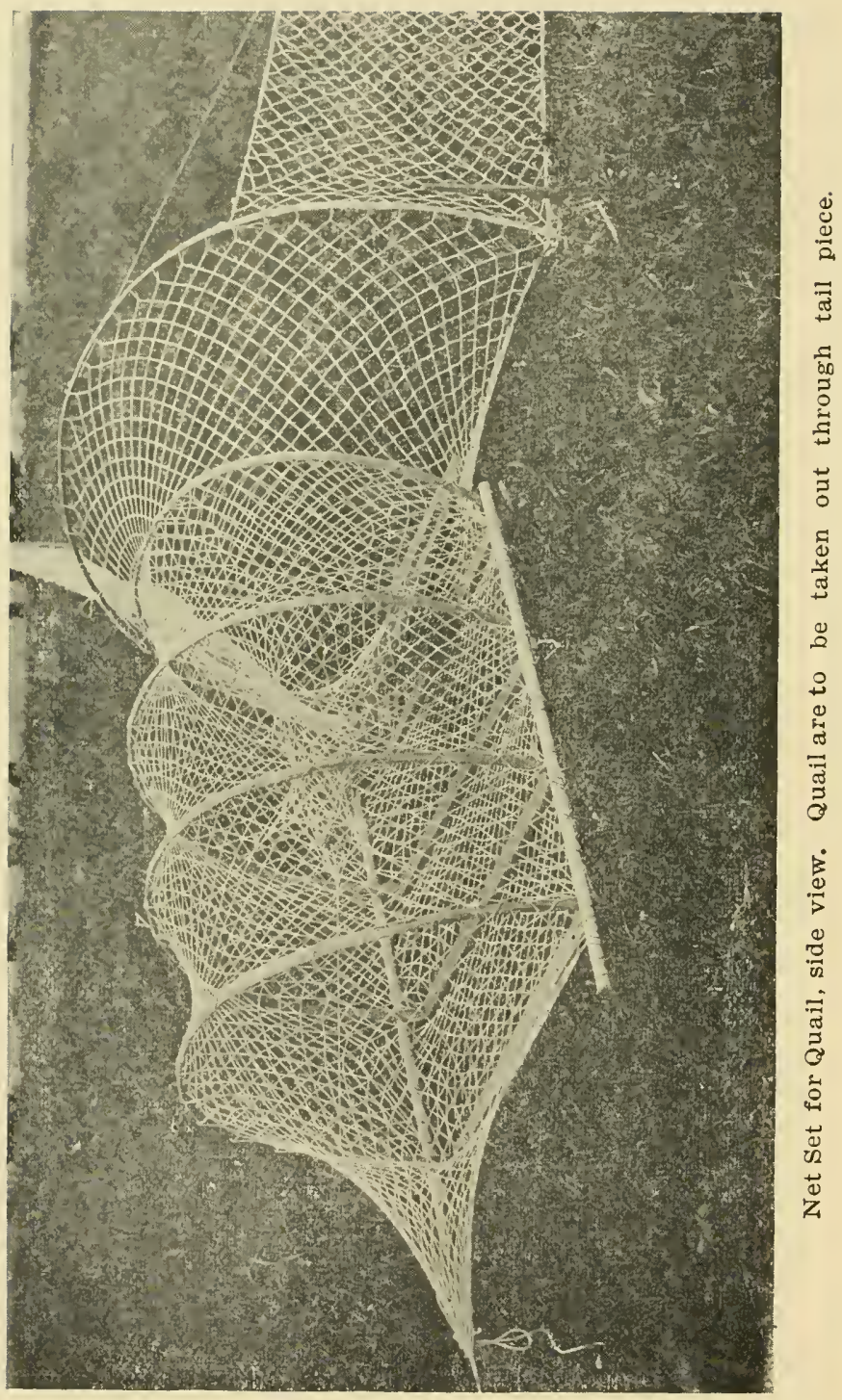




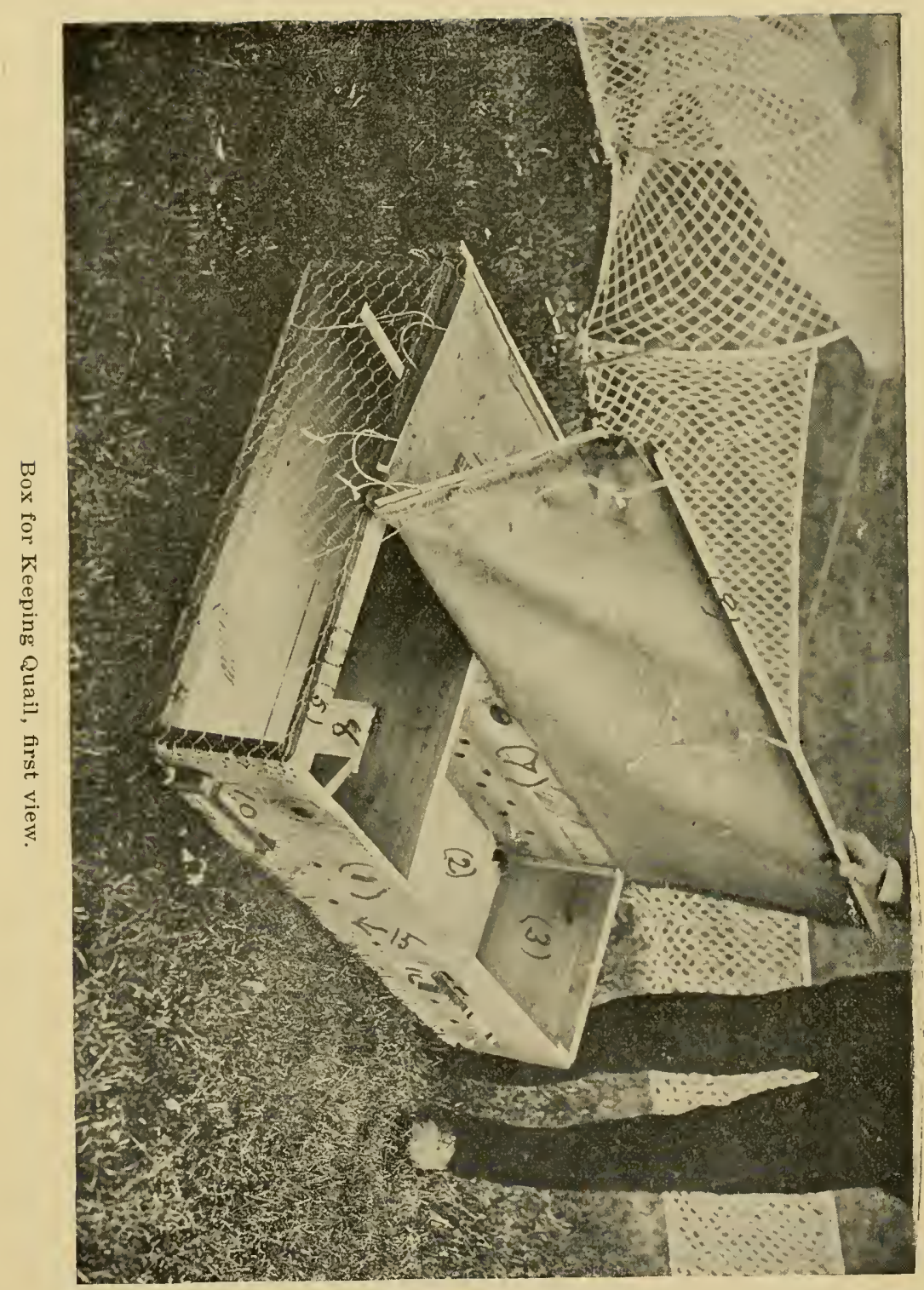






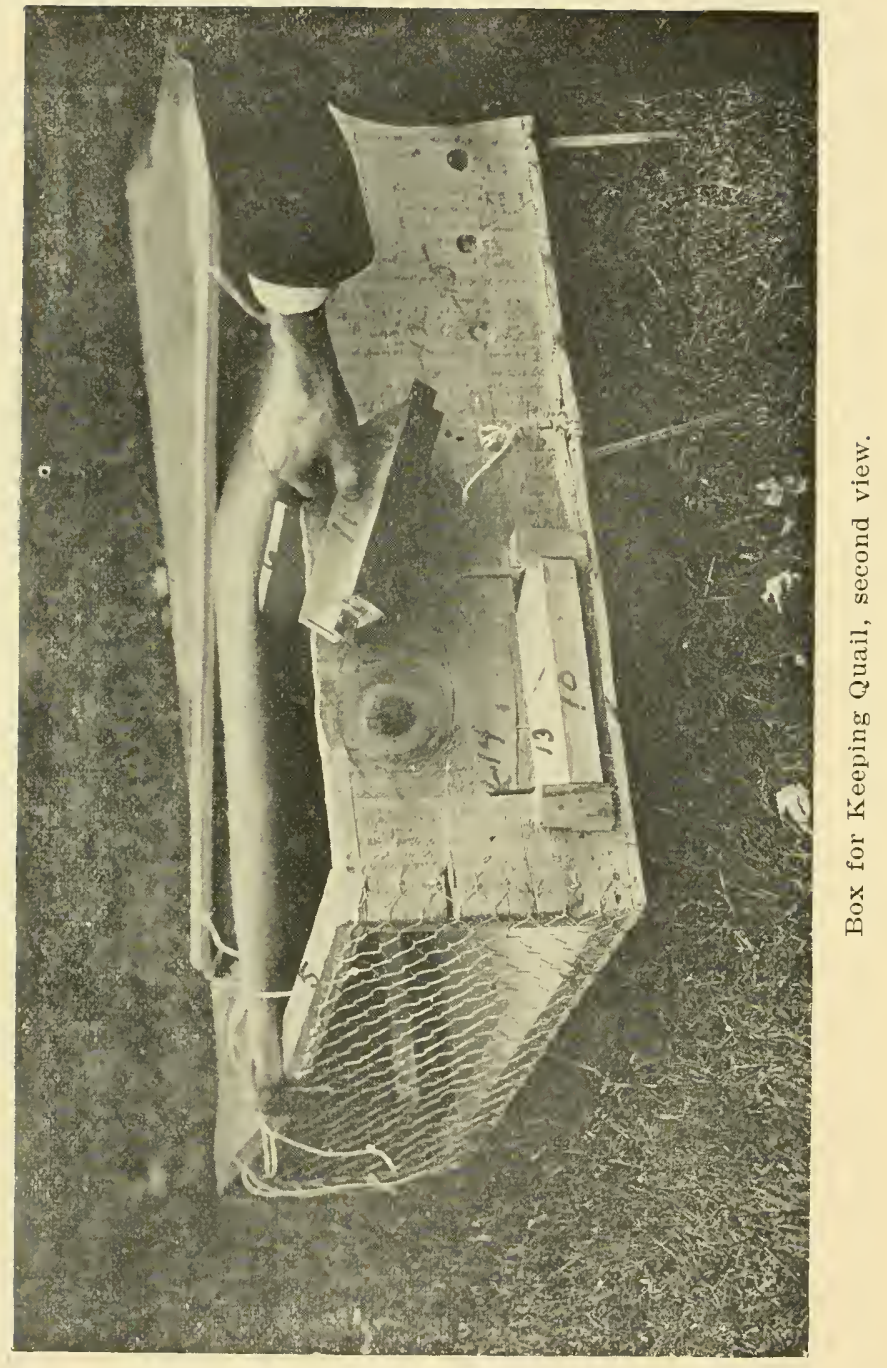


middle. The cloth top can be drawn as tight as you please by means of these strings. Ends can also be tied thus cutting off all arenues of escape.

In the side of one of the dark compartments I suggest an opening with door, in size about as iu the inside partition, (16) so placed that all parts of said compartment can be reached with your hand thrust through this opening. The birds in this way can be taken at pleasure without danges of eseape to the remainder of the bunch.

I have experimented with a box of this kind and feel confident I can keep three or even four dozen quail through the entire winter in a coop of this size and construction. Quail are active and energetic and need plenty of room for exercise. The more room the better for them, and I only suggest this size. Larger boxes can be made if considered necessary. Points to be especially remembered are:

\section{Points to be Especially Remembered.}

The birds slould always be kept out of reach of vermin. Coops should be placed where they are safe from house eats.

They should be kept in a cool and airy place. Never in a room artificially heated.

They should be fed and watered regularly. Quail are great drinkers and should not be stinted in their supply of water. See to it that your troughs are large and that plenty of fresh water is supplied daily.

Mixed food, such as buckwheat, cracked corn, screenings, millet, etc., is best.

Coops should be cleaned frequentiy.

Sand and gravel are as necessary as food.

Road dust or wood ashes should be supplied at least once a week. otherwise rou may have trouble with lice.

I think it very important that the boxes or coops should in no instance be higher than twelve inches, nine inches seems to me to be about the correct measure. If the boxes are made too high the birds are very apt to injure themselres in an attempted flight or efiort to escape. If too low they are liable to injure the tops of their heads by jumping up against the cover. This disposition of quail to jump makes the placing of a soft corer to the box or coop imperative.

By this method many more birds will be sared than in any other way, as they will not be exposed to storms and to the attacks of their natural enemies. If a room or coop cannot be secured, hang up bundles of unthreshed grain, wheat, rye, buckwheat, millet, or anything that will supply the need, or, better still, build covers 
under which they can feed, choosing warm, protected corners along fences for this purpose. A good way is to drive two stakes, say ten feet apart, and ten feet from the fence, lay a rail on the stakes, and rails from the fence to this rail, cover with brush or corn stalks. Be sure to leave all sides open, so that the birds, if attacked by an enemy', such as a weasel, or house cat, can readily make their escape. Build the cover about three feet high, so that while there will be plenty of light and air, it will be almost impossible for a hawk to strike the birds while feeding, which will be done if the cover is too high; scatter feed both threshed aud unthreshed under this cover, see to it that your efforts are not undone by hawks, or house eats, or other predatory creatures. Two or three covers of this kind will serve a good purpose on any farm, and be followed by a full return of money and labol expended, through the work of the birds.

Experience teaches: That the idea of giving absolute protection to quail for a series of years, or to certain coveys on a farm, is not followed by the best results, unless the covey be trapped and separated, because frequently two or three or more hen birds will lay in the same nest, the cock birds fight over them, and no hatching be the result. I therefore recommend the trapping of the birds in every instance where it is possible, not only for the purpose of keeping then alive during the winter, but also for the purpose of sepalating a covey to increase the chances of propagation. Where the birds are trapped they can well be allowed to run together during the.greater part of the winter. Two or three weeks before they are to be liberated, divide them into pairs, placing a male and female in a separate box or cage, feed and keep together. The probability is that the birds will mate, in captivity, or at least become so well acquainted that they will mate after their release. This will result in a corey for each pair of birds. By taking the cage or box in which the birds are confined, during the night time, to the place where one hopes to see the birds propagate, taking off the cover or slats, sprinkling food around, and going away quietly, the birds, when daylight comes, will be induced to come out without fright, will feed, move around, feed again, and remain in that locality, without flying to places where they cannot be looked after, or protected.

Another good method is to take the birds to be released into the territory where you wish to place them. Take each bird securely in your hand, leach as far as possible into a brush pile and free the bird. A pair, or two, or more can be placed in this way with very little trouble. In selecting a location for the birds be sure that they are placed near rumning water and where plenty of cover, such as briars and brush abound. Don't forget to scatter food frequently, say once or twice a week, at least, until the time comes when vegetation starts and insects become plentiful. 
A little judicious liandling and feeding will in all probability keep them there until the young are hatched, and frequently cause them to make that place their permanent home. If the covey you have trapped is released in pairs, on different days, on different parts of the farm, the probability is that they will not call together, but instead, will at once make preparations for housekeeping, with the result that several coveys will be found where rou now have but one.

It is a well known fart that the male bird generally leads in the flight. I would suggest, therefore, as a means of keeping a pair of quail in a certain locality, that about two days before releasing the birds you pluck five of the large feathers from the tip of one wing of the male bird; this, while not taking from the bird absolutely the power of flight, will cause it to fly in circles and prevent lengthy flights. The feathers will be renewed in about six weeks; in the meantime the birds will become fixed in the locality, and in all probability have housokeeping started.

Syortsmen and other's interested in the preservation of the wild turkey should see to it that food of sufficient quality and in sufficient quantity be procured and placed during the winter months where it can be secured readily by these birds.

I understand and appreciate the ferling of the farmer or fruit grower who sees the birds destroying his berries or his fruit. Those who drafted the law giving protection to these birds also understood this situation and notwithstanding the great benefit the agriculturist or the horticulturist derived through the life work of these same birds during that period when there were no berries and no fruit, said that birds of all description caught in the act of destroying "fruit or cereals" might be killed by the owner thereof. The propriety or justice of such a provision I will not attempt to discuss. but congratulate myself in the thought that no game birds are likely to be caught in such an act. I know too that it is not their disposition to destroy cultivated fruits or berries and that the grain they may consume is chiefly that left mon the ground and abandoned by the farmer. I am sure too that the great majority of our people have better judgment than to kill our birds for such reasons.

The law also permits the owner or the lessec of real estate or any member of his $0^{2}$ their family and those in their immediate employ, as a protection to trees or growing crops, to kill rabbits during the closed season. I know that it is very aggravating to see the fresh sprouts,--beans or peas or beets or other vegetablesmowed down by the rabbit and cannot say that I should altogether blame the man who kills birds in the act of destroying his fruit, or the rabbit when known to be mutilating trees or destroying regetables, if this killing was the only remedy and was actually neces- 
sary. All $I$ ask is that you be sure you are right before you kill either birds or animals.

Prof. Surface says the best remedy for the bird evil, if it can be so termed, is to plant an excess of berry plants and bushes or fruit trees beyond your needs, so that, although the birds may take a goodly share, you will still have enough and to spare. The professor asserts that the benefit derived from the birds through the destruction of injurious insects repays the famer man times orer for any or all frnit that may be taken. I know that a woren wire feace two feet high and one inch mesh will protect the garien from rabhits and have been informed by good authority that rabbits will in all instances refuse to cat anything upon which coal nil has been sprinklod, my informant stating that a mixture of one tablespoonful of oil to a gallon of water sprayed orer the growing garlen, while not in any way affecting or injuring the plants, wonld be most effectual in warding off the attaclis of rabbits. This applies to all growing things, trees as well as veretables.

I, some three years ago, had an orchard seriously injuref by rabbits or mire, or both. Inrdy a single tree ont of an hundred or more escaped unscathe Is soon as the condition was noticed, which was ant until many of tiem had been absolutely ruined, each tree was treated to the heighth of about one foot with ordinary axil grease, that preparation being highly charged with coal tar. Dead trees were replaced in the spring by living trees, which were also greased. Two winters have passed since that time and but one single tree has been distubed, that one a small peach tree, which I have reason to believe escaped the grease. I presume there are many other effective remedies.

The rabbit fills an important niche in the econony of nature. Asire from the henefits of recreation derived through hunting, he is a raluable source of food supply to many creatures other than human beings, and owing to the fact that he moves in the seareh of food chiefly in the early evening or at night, is the more readily seen and taken by the for or owl or other night predatory prowier. The more rabbits we have the less liable are foxes and owls and weasels and other animais of this character to frey upon our game birds or mon the farmer's nonltry. The more rabbits we have the less game birds will be killed by the hunter for the domble reason, as I believe, that the groat majority of hunters prefer to shoot rabbits rather than birds, and I know that whin a rabbit hunter and his dog enters an open field or brusl lot in the morning, every game bird in that section hikes to tall timber or more dense corer. The rabbit rog raises the biris too far ahead of his master to be shot, eren were he thus disposer. When the bird hunter comes alnng later, mach to his chagrin he finds himsclf entirely cut ont. The 
rabbit hunter and his dog are looked upon by the bird hunter about as the sheep man on the plains is viewed by the cattle man, that is with no specially kind feeling or regard, rather the contrary.

The birds and the rabbits each have their place to fill and are each in their place doing more good than wrong.

POISON.

We have in this State a law, just and proper, that forbids the placing of poison for the purpose of intentionally killing domestio animals or dogs. The penalty for violation of this act includes imprisonment, as well as a cash penalty. There is still another law that forbids the placing of poison outside of buildings for the purpose of killing wild animals or birds. Still, the Game Commission, through its duly authorized agents, has the right under the law to destroy vermin and predatory wild animals and birds harmful to game and other wild birds in such a ray as to them may seem best.

Experience teaches us that it is next to impossible to reach many of the wild predatory creatures of our State except through the use of poison. I take it the purpose of placing poison may well be judged from the point where it is deposited or the vehicle used to convey it, and, therefore, in attempting to select methods of conveyance for this remedy, have tried to decide upon certain things not likely to be taken by domestic animals of any kind or by a dog. I found that by introducing as much stryclinine as will be taken up by an ordinary musket cap into the body of an English sparrow, a mouse, a piece of fish or eel, and dropping same into a stone wall or stone pile, hollow log, or stump along the line of travel of vermin, many animals such as the skunk, the weasel, the mink, and the honse cat will be stopped in its predatory career, and such action will add tenfold to the safety of the quail, the wild turkey, the pheasint or any other ground nesting or grund feeding birds. The fead body of a rabbit or a chicken or sparrow or mouse, treated in this way, tied to the end of a stick, say two feet in length, placed in the hollow of a tree near the ground, bait end up, so that the lower portion of the poisoned bait will be above the top of the opening will serve a splendid purpose. Poison nay be used in perfect safety in the above ways, the dog not being able to get at it, even if so disposed, while smaller animals will be able to reach it easily.

One gentleman recently told me of three reasels he killed in this way with one bait, the bait in this instance being the body of a rabbit killed by a weasel. A dog is not likely to eat any of the aforementioned bait, even if he should find it in the woods. If placed as directed it will be out of reach, should he pass that way. When the warm rains begin bait of this kind will quickly be decomposed and rendered harmless, even should it not be taken by rermin. Many a predatory animal and bird will be called down in this way without 
the aid of a bounty law, or the expense attached thereto. Untold numbers of rats and mice will also be killed, far more in my opinion than would or could be killed by the foxes or weasels, and with no harm to birds.

The good done by the crow through the destruction of mice or insects does not appear to weigh in the balance against the wrong done by these same birds. The rapid disappearance of prairie chicken in Indiana, Illinois and other prairie States of the west is directly attributable to the crow, that, from morning to night, month in and month out, preys upon the nests and young of these birds, and has been known in very many instances to attack and kill nearly full grown prairie chickens.

Dr. Warren tells me of a spot in Pennsylvania known to himself where the ground, during the laying and nesting time of the wild waterfowl, especially the mud hen, is covered to the depth of many inches by the shells of the eggs of these birds, all of which were stolen by crows, that, in scores and hundreds, sweep orer the marshes in that locality, devouring every egg and destroying every young bird they can find. We all know how the robin and very many other of our small birds, during their nesting time, are driven almost to the window sills of our home by the voracious crow, which, to $\mathrm{my}$ mind, seem to destroy individually more birds of all kinds, more birds' e'ggs and more young poultry than any hawk that ever flapped a wing. A little corn boiled until swollen and soft, with the addition of a little strychnine, will cure the crow of many bad habits. Coln thoroughly soaked in strong salt water will have the same effect upon crows. The brine of a mackerel tub is just the thing for this purpose.

Corn prepared in this manner should in all instances be so placed in a pile, on a board, on a piece of paper, or in such other manner, as to make its removal easy and complete, after it has serred the specific jurpose intended. It should never be scattered over a field or be left exposed longer than is absolutely necessary to accomplish the object in riew.

The question of placing poison has been considered in rery many phases. Experiments of various descriptions have been tried, some upon chickens, some with ducks, some upon turkers, some upon quail and upon different kinds of wild birds other than game birds. One gentleman, a prominent physician, told me of feeding nux romica to a chicken, a common hen, in quantities sufficient to have pro. duced fully fifteen grains of strychnine with no injurious result to the hen. The gentleman saying, the only visible effect so far as he could see, was that the hen appeared to have lost confidence in him. Six quail were repeatedly given excessive doses of strychnine, enongh at each time and to carh bird to hare caused the death of 
several men. The birds seemed to have been wholly unaffected by the poison. One of these birds was afterwards killed by having forced into its craw two or three times the quantity administered in the first instance. Turkeys withstood excessive doses of this poison, while a duck quickly succumbed, after swallowig a small quantity. Crows and blackbirds were easily killed by the administration of small doses. I learned from a reliable source that residents of certain countries had for long periods been in the habit of mixing nux vomica with the food given their chickens at certain times-the purpose being to kill hawlis-and that while the poison did not appear in any way to affect the chicken, it was sure to kill any hawk that might within the limits of several hours or days, partake of a chicken thus impregnated. While none of these experiments have been carried to an absolute conclusion, they did determine beyond question, that a fixed quantity of strychnine would not affect all animals and birds in the same way. That many birds appear to be absolutely immune to its effects; that they are wholly unaffected by a dose in quantity sufficient to kill several men; and that many four-footed animals are easily killed through the use of this agent. While our protector's found the dead bodies of many animals killed by this poison, they have not yet discovered the body of one single dead bird, either game or otherwise, apparently determining beyond question, that strychnine is the solution of the vermin problem, and that when administered as directed by this office in a special vehicle, such as the dead body of a sparrow, or a piece of fish, both of which decompose quickly, and disappear, placed in a special locality, namely on the wild lands of the State; and at a special time, namely, late in the fall, after the close of the game season, and again early in the spring, nothing but good and benefit to the State can result.

Read what Powers and Weightman, manufacturers of drugs, Philadelphia, say upon this subject:

\section{"STRYCHNINE."}

Te are occasionally solicited, by persons interested in the poisoning of wolves, squirrels, gophers, and other destructive animals, to suggest some preparation quicker to act, and more certain in results, than Strychnine; but, we known of none.

Strychnine, when of good quality is very active, and excessively poisonous. Its results, as a rule, are quick, uniform, and certain. While this is so, however, and while it operates in the same way upon almost all animals, when the system has been brought decidealy under its influence, (producing violent tonic spasms of the muscles, like those of tetanus), yet, considerable variation is found in different individuals to resist the poison. 
Some persons are powerfully affected by the smalles

00028564661 half a grain of Sulphate of Strychnine has produced death in fourteen minutes, while a case is recorded in which recovery took place after seven grains of Strychnine had been swallowed.

So, in the lower animals, it is found that all are not equally susceptible. One sixth-even one eighth-of a grain, it is said, will kill a large dog. Ten times as much Strychnine is required to kill chickens as other birds, weight for weight; and among mammals the guinea-pig is very insensitive to it.

Where those interested in the destruction of wolves, etc., fail to obtain expected results, they are apt to question the purity of the Strychnine; but, we think it may safely be asserted, that the Strychnine found in our markets is of good quality, and the fault is not with the poison itself.

Experieuce will suggest to the trapper and hunter, more accurately than the manufacturer can do, the required amount to be used, and the best methods of preparing the bait. It will also remind him that more Strychnine is required to kill a large, than a small animal; that where size is about the same, some may be able to resist a dose that would be fatal to others; and that the same animal may not be, at all times, equally susceptible to its power.

Remember, the law prohibits the placing of poison by the general public in Pennsylvania."

Remember, in using strychnine, that it is a deadly poison, and should in all ways be most carefully handled and cared for.

\section{TREATMENT OF STRYCHNINE POISONING.}

The antidote is tannic acid to form the insoluble tannate, or a soluble salt of iodine. Then emetics or the stomach pump, followed by perfect quiet, which is rery important. Vomet as quickly and as thoroughly as possible. A teaspoonful of common salt to a pint of warm (not hot) water makes a splendid and thorough emetic. Drink as much water thus prepared as possible, then stick your finger down jour throat. Antagonists are chloral, chloroform, chamomile oil, physostigma, tobacco and potassinm bromide, the latter being so slow of action it is rarely arailable. The bladder must be frequently evacuated, to prevent re-absorbtion of the poison.

If poisoned, use any of these remedies that can be the most easily obtained and send for your physician at once.

I feel that nothing but good can come to the State by the following of any of the suggestions herein made.

Respectfully yours.

JOSEPH KALBFUS, Secretary of the Game Commission. 

LIBRARY OF CONGRESS

| I| || || || || || || || ||

| |. $\mid$ | $\mid$ ||

II III II II IIIIIII

00028564661

Hollinger Corp. $\mathrm{pH} 8.5$ 